\title{
PENGARUH GAYA KEPEMIMPINAN TRANSAKSIONAL, TRANSFORMASIONAL DAN DISIPLIN KERJA TERHADAP KINERJA GURU (KARYAWAN) DI KOTA MADIUN
}

\author{
Satrijo Budiwibowo*
}

\begin{abstract}
Transactional leadership is described as providing an explanation of employees responsibilities and rewards they can expect if the specified standards is achieved. Transformational leadership approach motivates employees, so that they can thrive and achieve high levels of performance. In addition it is also necessary to support the performance of the good discipline of employees. Broadcasting companies who have employees working on the division of operational and management needed different leadership style to support the realization of optimal performance.

This study used a qualitative approach. Sample was 136 people who are determined by purposive sampling technique. The research instrument used Likert scale models. Data analysis using validity test, realibitas test, the classical assumption, hypothesis testing, multiple linear regression analysis, analysis of correlation coefficients and determination.

The results showed that together transactional leadership styles, transformational leadership styles, work discipline affect the performance of the company's employees broadcasting. Partially transactional and transformational leadership style had no effect on performance. And partially work discipline most dominant effect on performance.
\end{abstract}

Keywords: Influence of Transactional, Leadership Style and Discipline Performance

\begin{abstract}
Abstrak
Kepemimpinan transaksional yang digambarkan sebagai kepemimpinan yang memberikan penjelasan tentang tanggung jawab karyawan serta imbalan yang dapat mereka harapkan jika standar yang ditentukan tercapai. Kepemimpinan transformasional yang menggunakan pendekatan memotivasi karyawan, sehingga dapat berkembang dan mencapai kinerja pada tingkat yang tinggi. Selain itu untuk mendukung kinerja juga diperlukan disiplin yang baik dari karyawan. Perusahaan penyiaran yang mempunyai karyawan yang bekerja pada divisi manajemen dan operasional membutuhkan pendekatan kepemimpinan yang berbeda untuk mendukung terwujudnya kinerja yang optimal.

Penelitian dilakukan menggunakan pendekatan kuantitatif, jenis penelitian ini adalah korelasi (correlation research) yang bertujuan mempelajari hubungan dua variabel atau lebih. Metode penelitian yang digunakan adalah nonprobability sampling. Sedangkan teknik yang digunakan dalam penarikan sampel adalah sampling jenuh yang berjumlah 90 orang. Instrumen penelitian yang digunakan model Skala Likert.
\end{abstract}

* Satrijo Budiwibowo adalah Dosen Prodi Pendidikan Akuntansi dan Ketua LPPM IKIP PGRI Madiun 
Analisis data menggunakan uji validitas, uji realibitas, uji asumsi klasik, uji hipotesis, analisis regresi linier berganda, analisis koefisien korelasi dan analisis koefisien determinasi.

Hasil penelitian menunjukkan bahwa secara bersama-sama gaya kepemimpinan transaksional, transformasional, disiplin kerja berpengaruh terhadap kinerja karyawan perusahaan penyiaran. Secara parsial gaya kepemimpinan transaksional dan transformasional tidak berpengaruh terhadap kinerja. Dan disiplin kerja berpengaruh paling dominan terhadap kinerja.

Kata Kunci: gaya kepemimpinan transaksional, transformasional, disiplin dan kinerja

\section{A. Pendahuluan}

Gaya kepemimpinan pada dasarnya mengandung pengertian sebagai suatu perwujudan tingkah laku dari seorang pemimpin yang menyangkut kemampuannya dalam memimpin. Menurut Stephen P. Robbins dalam Irham Fahmi $(2012 ; 15)$, kepemimpinan adalah kemampuan untuk memengaruhi suatu kelompok ke arah tercapainya tujuan. Disisi Maulizar $(2012 ; 4)$ berpendapat bahwa konsep kepemimpinan yang berkembang pesat adalah konsep kepemimpinan transaksional dan transformasional yang kemudian dipopulerkan oleh Bass pada tahun 1985. Kedua konsep kepemimpinan tersebut berbasiskan pada gaya, perilaku dan situasi seorang pemimpin. Kepemimpinan transaksional berdasarkan prinsip pertukaran imbalan antara pemimpin dengan bawahan dimana pemimpin mengharapkan imbalan berupa kinerja bawahan yang tinggi sementara bawahan mengharapkan imbalan dan penghargaan secara ekonomis dari pemimpin. Sedangkan kepemimpinan transformasional mendasarkan diri pada prinsip pengembangan bawahan (follower development). Pemimpin mengembangkan dan mengarahkan potensi dan kemampuan bawahan untuk mencapai bahkan melampui tujuan organisasi.

Penerapan gaya kepemimpinan yang sesuai akan mendukung tercapainya tujuan organisasi yang akan nampak dari kinerja sebuah organisasi. Peningkatan kinerja ini didukung oleh sikap dasar pegawai, dalam hal ini pendidik dan tenaga kependidikan terhadap diri sendiri (disiplin) dan kompetensi. Disiplin kerja adalah sikap dan perilaku seorang guru dan karyawan yang diwujudkan dalam bentuk kesediaan seorang guru dan karyawan tersebut dengan penuh kesadaran dan keikhlasan atau dengan paksaan untuk mematuhi dan melaksanakan tugas dan tanggung jawabnya. Fenomena-fenomena seperti adanya: guru datang terlambat, karyawan melalaikan tugas dan tanggung jawab serta melanggar peraturan disiplin kerja yang diterapkan sekolah. Dengan adanya kondisi tersebut maka setiap sekolah pasti memiliki aturan dalam rangka menjalankan disiplin kerja para guru dan stafnya

Dengan adanya gaya kepemimpinan dan disiplin tersebut guru dan karyawan diharapkan dapat meningkatkan produktivitas perusahaan yang diukur dengan kinerja karyawan dalam perusahaan (Wahyu Wijayanto, 2012; 2). Kinerja merupakan suatu keadaan yang menunjukkan banyaknya pekerjaan yang harus dilakukan atau dihasilkan seorang individu atau kelompok kerja sesuai dengan job description masing-masing. Kinerja suatu perusahaan atau organisasi merupakan akumulasi kinerja semua individu yang bekerja di dalamnya. Dengan kata lain 
upaya peningkatan kinerja perusahaan adalah melalui peningkatan kinerja masingmasing individu (Usnul Khotimah, 2013;5).

Beberapa penelitian tentang pengaruh gaya kepemimpinan transaksional, transformasional dan disiplin kerja terhadap kinerja yang pernah dilakukan menunjukkan hasil yang berbeda-beda. Seperti penelitian yang dilakukan oleh: Munawaroh $(2011 ; 1)$, hasil penelitian menunjukkan bahwa gaya kepemimpinan transformasional dan transaksional secara parsial maupun bersama-sama berpengaruh terhadap kinerja guru, sedangkan gaya kepemimpinan transformasional berpengaruh lebih dominan. Kemudian terdapat pula penelitian yang lain, yaitu: Andira dan Budiarto S (2009; 1), hasil penelitian ini secara umum jenis kepemimpinan transformasional berpengaruh secara positif pada kinerja karyawan lini depan perusahaan jasa dan jenis kepemimpinan transaksional berpengaruh negatif.

Sedangkan penelitian lain yang dilakukan oleh Nurjannah dan Didin M (2012: 1), menunjukkan hasil yang berbeda yaitu secara simultan gaya kepemimpinan, motivasi dan disiplin berpengaruh terhadap kinerja. Dan secara parsial gaya kepemimpinan dan motivasi berpengaruh terhadap kinerja sedangkan variabel disiplin tidak berpengaruh terhadap kinerja.

Dari beberapa penelitian tersebut dapat dirumuskan research gap sebagai berikut : Terdapat perbedaan temuan tentang pengaruh gaya kepemimpinan transaksional terhadap kinerja perusahaan, beberapa penelitian menunjukkan pengaruh positif namun ada penelitian yang menunjukkan pengaruh negatif. Adanya pengaruh disiplin kerja yang signifikan terhadap kinerja dan terdapat penelitian yang menyatakan disiplin kerja tidak berpengaruh terhadap kinerja. Berdasarkan research gap dan fenomena yang ada, maka perlu dilakukan penelitian lebih lanjut dengan judul "Pengaruh Gaya Kepemimpinan Transaksional, Transformasional dan Disiplin Kerja Terhadap Kinerja Sekolah"

\section{B. Batasan Masalah}

Adanya berbagai macam jenis gaya kepemimpinan, seperti: gaya kepemimpinan kharismatik, visioner, transaksional, transformasional maka penelitian ini dibatasi pada masalah pengaruh gaya kepemimpinan transaksional, transformasional dan disiplin kerja terhadap kinerja Guru.

\section{Rumusan Masalah}

Berdasarkan latar belakang tersebut maka rumusan masalah dalam penelitian ini adalah

1. Apakah gaya kepemimpinan transaksional secara signifikan berpengaruh terhadap kinerja karyawan?

2. Apakah gaya kepemimpinan transformasional secara signifikan berpengaruh terhadap kinerja karyawan?

3. Apakah disiplin kerja berpengaruh secara signifikan terhadap kinerja karyawan?

4. Apakah gaya kepemimpinan transaksional, gaya kepemimpinan transformasional dan disiplin kerja secara simultan berpengaruh terhadap kinerja karyawan? 


\section{Landasan Teori}

Kinerja merupakan hasil atau yang diperoleh dari sebuah pekerjaan sebagai konstribusi terhadap perusahaan. Kinerja merupakan suatu fungsi dari motivasi dan kemampuan. Mengacu pada Rivai dan Basri (2005: 14) kinerja adalah hasil atau tingkat keberhasilan seseorang secara keseluruhan selama periode tertentu di dalam melaksanakan tugas dibandingkan dengan berbagai kemungkinan, seperti standar hasil kerja, target atau sasaran atau kriteria yang telah ditentukan terlebih dahulu dan telah disepakati bersama. Menurut Gibson (dalam Ahmad Fachri, 2010), ada tiga faktor yang berpengaruh terhadap kinerja, yaitu:

1) Faktor individu: kemampuan, keterampilan, latar belakang keluarga, pengalaman kerja, tingkat sosial dan demografi seseorang.

2) Faktor psikologi: persepsi, stres kerja, peran, sikap, kepribadian, motivasi dan kepuasan kerja.

3) Faktor organisasi: sturktur organisasi, desain pekerja, kepemimpinan, sistem penghargaan.

Menurut (Siagian 2006; 169) dalam Usnul Khotimah (2013), terdapat tujuh elemen kunci dalam penilaian kinerja, yaitu:

1) Sasaran penilaian kinerja adalah para karyawan sehingga diperoleh informasi yang akurat mengenai kinerja tersebut.

2) Standar kinerja digunakan sebagai alat ukur.

3) Alat pengukur kinerja ciri-cirinya adalah mudah digunakan, dapat dipercaya, menunjukkan perilaku yang kritikal, dapat didiversifikasi orang lain, mengukur kinerja yang ditampilkan secara reguler.

4) Menghasilkan penilaian kinerja yang objektif.

5) Hasil penelitian kinerja harus dicatat secara akurat dan lengkap dalam arsip kepegawaian setiap karyawan.

6) Bahan informasi yang diperoleh dari penilaian kinerja akan digunakan oleh manajemen untuk berbagai kepentingan pengambilan keputusan.

7) Penilaian kinerja merupakan kegiatannya yang sifatnya siklikal. Artinya secara berkala dalam kehidupan kekayaan seseorang dalam organisasi.

Faktor-faktor yang memengaruhi kinerja menurut Mangkunegara (dalam

Jeriko Siahaan, 2008) adalah: kemampuan (ability), motivasi (motivation), disiplin (discipline) dan gaya kepemimpinan (leadership).

1) Kemampuan (ability)

Secara psikologis kemampuan karyawan terdiri dari kemampuan potensi (IQ) dan kemampuan reality (knowledge dan skill). Oleh karena itu karyawan perlu ditempatkan pada pekerjaan yang sesuai dengan keahliannya.

2) Motivasi (motivation)

Motivasi terbentuk dari sikap dalam menghadapi situasi kerja. Motivasi merupakan kondisi yang menggerakkan diri karyawan terarah dalam mencapai tujuan organisasi.

3) Disiplin (discipline)

Disiplin merupakan ketaatan dan kepatuhan dalam menjalankan peraturan yang berlaku. Peningkatan disiplin SDM sangat diperlukan untuk mencapai produktivitas organisasi sesuai yang diharapkan. 
4) Gaya kepemimpinan (leadership)

Gaya kepemimpinan adalah tindakan untuk memengaruhi orang lain. Demi terwujudnya tujuan yang diharapkan maka diperlukan penerapan gaya kepemimpinan yang sesuai dengan organisasi tersebut.

Kepemimpinan merupakan salah satu fungsi manajemen yang sangat penting dalam upaya pencapaian tujuan. Kepemimpinan merupakan kegiatan pemimpin dalam hal memengaruhi, mendorong dan membimbing serta mengarahkan kegiatan orang lain agar mampu menerima pengaruh itu dan selanjutnya dapat membantu pencapaian tujuan yang telah ditetapkan oleh perusahaan. Pengertian kepemimpinan secara luas menurut Richard L. Draft (dalam Irham Fahmi; 2011: 15) adalah: "Kepemimpinan (leadership) adalah kemampuan memengaruhi orang yang mengarah kepada pencapaian tujuan".

Pendapat ini menekankan bahwa kepemimpinan adalah proses untuk memengaruhi karyawan (pengikut) atau sekelompok orang (termasuk perilaku/ budayanya) agar dapat berubah sesuai dengan keinginan organisasi dalam upaya mencapai tujuan yang ditetapkan.

Menurut Roach \& Behling (dalam Sarlito W.S; 2005:39) kepemimpinan didefinisikan sebagai "Proses memengaruhi aktivitas sebuah kelompok yang terorganisasi menuju pencapaian suatu tujuan". Dari pendapat ini tampak bahwa kepemimpinan sebagai suatu proses yang melibatkan pimpinan, yang dipimpin (bawahan) dan situasi. Robbins (dalam Irham Fahmi, 2011: 15) mendefinisikan kepemimpinan sebagai "Kemampuan untuk memengaruhi suatu kelompok ke arah tercapainya tujuan".

Gaya kepemimpinan yang mencerminkan pola tingkah laku pemimpin dalam memengaruhi dan mengarahkan bawahannya sangat menentukan keberhasilan pencapaian tujuan organisasi. Berkaitan dengan gaya kepemimpinan, Stoner, Freeman dan Gilbert (2003: 165) mengemukakan bahwa gaya kepemimpinan mencerminkan berbagai pola tingkah laku yang disukai oleh pemimpin dalam proses mengarahkan dan memengaruhi pekerja.

\section{Gaya Kepemimpinan}

1. Gaya kepemimpinan kharismatik

Para pengikut terpacu kemampuan kepemimpinan yang heroik atau luar biasa ketika mereka mengamati perilaku-perilaku tertentu pemimpin mereka. Terdapat lima karakteristik pemimpin kharismatik:

a. Visi dan artikulasi, memiliki visi ditujukan dengan sasaran ideal yang berharap masa depan lebih baik daripada status quo dan mampu mengklarifikasi pentingnya visi yang dapat dipahami orang lain.

b. Rasio personal, pemimpin bersedia menempuh risiko personal tinggi, menanggung biaya besar dan terlibat dalam pengorbanan diri untuk meraih visi.

c. Peka terhadap lingkungan, mampu menilai secara realistis kendala lingkungan dan sumber daya yang dibutuhkan untuk membuat perubahan.

d. Kepekaan terhadap kebutuhan pengikut, sangat pengertian terhadap kemampuan orang lain dan responsif terhadap kebutuhan dan perasaan mereka.

e. Perilaku tidak konvensional, terlibat dalam perilaku yang dianggap baru dan berlawanan dengan norma.

2. Gaya kepemimpinan transaksional

Pemimpin transaksional merupakan pemimpin yang memandu atau memotivasi para pengikut mereka menuju sasaran yang ditetapkan dengan 
memperjelas persyaratan peran dan tugas. Gaya kepemimpinan transaksional lebih berfokus pada hubungan pemimpin-bawahan tanpa adanya usaha untuk menciptakan perubahan bagi bawahannya. Terdapat empat karakteristik pemimpin transaksional, yaitu:

a. Imbalan kontingen, kontrak pertukaran imbalan atas upaya yang dilakukan, menjanjikan imbalan atas kinerja baik, mengakui pencapaian.

b. Manajemen berdasar pengecualian (aktif), melihat dan mencari penyimpangan dari aturan dan standar, menempuh tindakan perbaikan.

c. Manajemen berdasar pengecualian (pasif), mengintervensi hanya jika standar tidak dipenuhi.

d. Laissez-faire, melepas tanggung jawab, menghindari pembuatan keputusan.

3. Gaya kepemimpinan transformasional

Pemimpin transformasional mencurahkan perhatian pada hal-hal dan kebutuhan pengembangan dari masing-masing pengikut, pemimpin transformasional mengubah kesadaran para pengikut akan persoalan-persoalan dengan membantu mereka memandang masalah lama dengan cara-cara baru, dan mereka mampu menggairahkan, membangkitkan dan mengilhami para pengikut untuk mengeluarkan upaya ekstra demi mencapai sasaran kelompok. Berikut karakteristik pemimpin transformasional:

a. Kharisma, memberikan visi dan rasa atas misi, menanamkan kebanggaan, meraih penghormatan dan kepercayaan.

b. Inspirasi, mengkomunikasikan harapan tinggi, menggunakan simbol untuk memfokuskan pada usaha, menggambarkan maksud penting secara sederhana.

c. Stimulasi intelektual, mendorong intelegensia, rasionalitas dan pemecahan masalah secara hati-hati.

d. Pertimbangan individual, memberikan perhatian pribadi, melayani karyawan secara pribadi, melatih dan menasehati.

4. Gaya kepemimpinan visioner

Kemampuan menciptakan dan mengartikulasikan visi yang realistis, kredibel dan menarik mengenai masa depan organisasi atau unit organisasi yang tengah tumbuh dan membaik dibanding saat ini. Visi ini jika diseleksi dan diimplementasikan secara tepat, mempunyai kekuatan besar sehingga bisa mengakibatkan terjadinya lompatan awal ke masa depan dengan membangkitkan keterampilan, bakat dan sumber daya untuk mewujudkannya.

\section{Disiplin Kerja}

Keberhasilan karyawan dalam menjalankan kewajibannya sangat tergantung pada kesediaan untuk berkorban dan bekerja keras dengan menjauhkan diri dari kepentingan pribadi atau golongan, maka perlu sekali dimiliki kedisiplinan dan mentalitas yang teguh serta memiliki pendirian yang tegas untuk bekerja secara efektif dan efisien sehingga tujuan perusahaan dapat tercapai.

"Disiplin adalah suatu alat yang digunakan para manajer untuk berkomunikasi dengan karyawan agar mereka bersedia untuk mengubah suatu perilaku serta sebagai suatu upaya untuk meningkatkan kesadaran dan kesediaan seseorang mentaati semua peraturan perusahaan dan norma-norma sosial yang berlaku (Rivai dan Jauvani, 2009:824). Menurut Stoner, Freeman dan Gilbert (2003:90) "disiplin ditegakkan bila seorang karyawan melanggar kebijakan perusahaan atau 
tidak memenuhi harapan hasil kerja dan manajer harus bertindak untuk mengobati situasi ini”".

\section{E. Kerangka Berpikir}

Kepala sekolah, guru dan karyawan merupakan aset penting bagi organisasi sekolah, banyak hal yang perlu diperhatikan terkait dengan pencapaian kinerja sekolah. Peningkatan kinerja organisasi sekolah seoptimal mungkin tidak terlepas dari penerapan disiplin dan gaya kepemimpinan yang efektif, yang merupakan faktor penentu pencapaian kinerja organisasi. Dari uraian pemikiran tersebut dapat diperjelas melalui variabel pengaruh gaya kepemimpinan dan disiplin kerja terhadap kinerja karyawan, secara skematis digambarkan seperti gambar di bawah ini.



Gambar 1. Kerangka Pemikiran

\section{F. Hipotesis}

Berdasarkan pada landasan teori dan kerangka pemikiran di atas, maka hipotesis dalam penelitian ini adalah sebagai berikut:

$\mathrm{H}_{1}$ : Terdapat pengaruh antara gaya kepemimpinan transaksional $\left(\mathrm{X}_{1}\right)$ terhadap kinerja karyawan $(\mathrm{Y})$.

$\mathrm{H}_{2}$ : Terdapat pengaruh antara gaya kepemimpinan transformasional $\left(\mathrm{X}_{2}\right)$ terhadap kinerja karyawan (Y).

$\mathrm{H}_{3}$ : Terdapat pengaruh antara disiplin kerja $\left(\mathrm{X}_{3}\right)$ terhadap kinerja karyawan $(\mathrm{Y})$.

$\mathrm{H}_{4}$ : Terdapat pengaruh gaya kepemimpinan transaksional $\left(\mathrm{X}_{1}\right)$, transformasional $\left(\mathrm{X}_{2}\right)$ dan disiplin kerja $\left(\mathrm{X}_{3}\right)$ secara simultan terhadap kinerja karyawan $(\mathrm{Y})$. 


\section{G. Desain Penelitian}

Desain penelitian merupakan gambaran alur dari penelitian yang dilakukan. Adapun desain penelitian sebagaimana tergambar dibawah ini

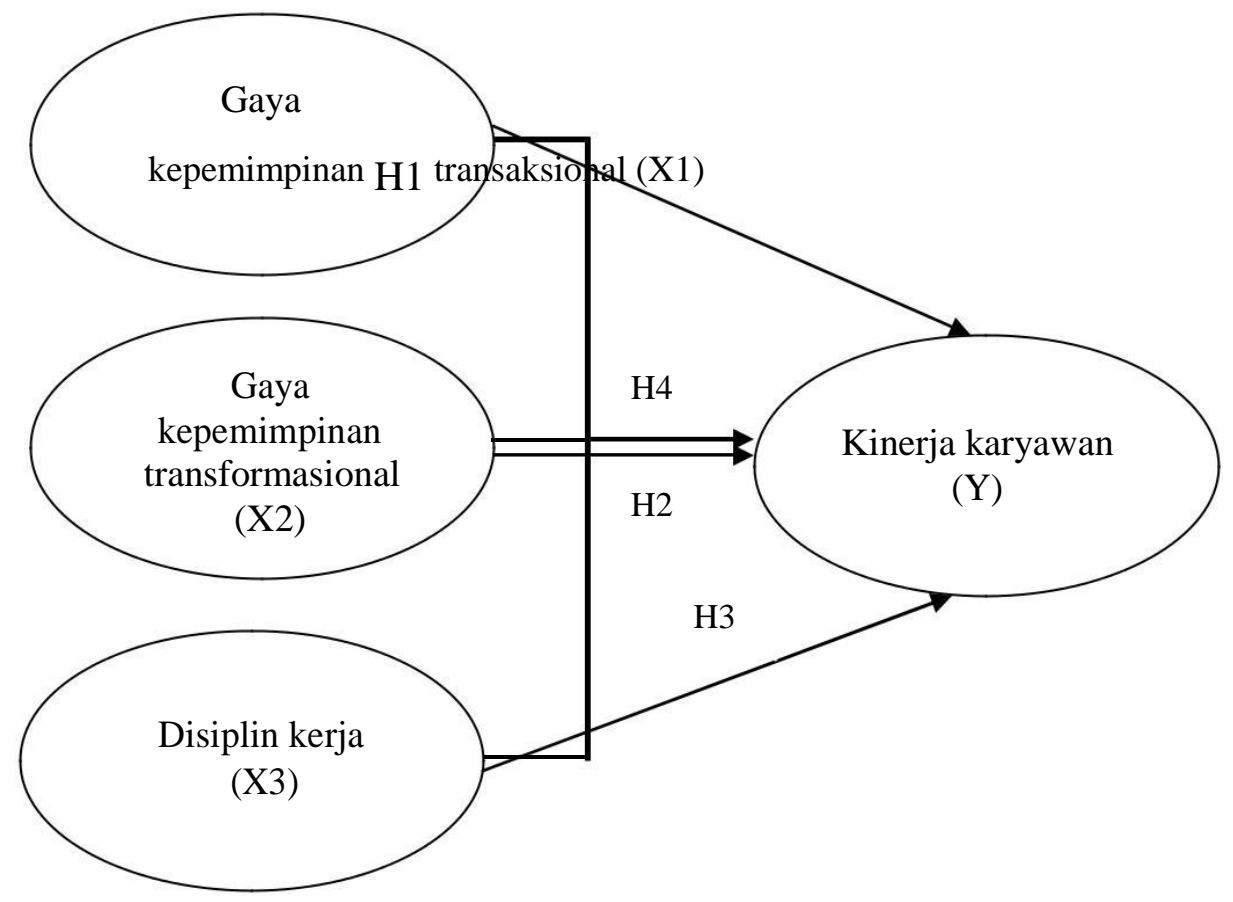

Gambar 2. Desain Penelitian

\section{H. Variabel Penelitian}

Pengertian variabel menurut Uma Sekaran (2010:115) adalah apapun yang dapat membedakan atau membawa variasi pada nilai. Nilai bisa berbeda pada berbagai waktu untuk objek atau orang yang sama atau pada waktu yang sama untuk objek atau orang yang berbeda. Berdasarkan pendapat diatas maka pada penelitian ini terdapat tiga variabel bebas yaitu gaya kepemimpinan transaksional dengan notasi $\left(\mathrm{X}_{1}\right)$, gaya kepemimpinan transformasional dengan notasi $\left(\mathrm{X}_{2}\right)$ dan disiplin kerja dengan notasi $\left(\mathrm{X}_{3}\right)$ serta satu variabel terikat yaitu kinerja karyawan (guru) dengan notasi (Y).

\section{Analisis Data}

\section{Uji t}

Pada penelitian ini dilakukan uji $\mathrm{t}$ yang fungsinya adalah untuk mengetahui pengaruh dari masing-masing variabel bebas $\mathrm{X}$ (secara parsial) dengan variabel terikat $(\mathrm{Y})$. Tingkat signifikan masing-masing variabel independen dapat disimpulkan dengan kriteria sebagai berikut:

a. $\quad \mathrm{a}=5 \%$ dengan df $(\mathrm{n}-\mathrm{k}-1)=90-3-1=86$

$\mathrm{t}_{\text {tabel }}=1,664$

b. Kriteria pengujian:

- Ho ditolak dan Ha diterima jika $t$ hitung $>t$ tabel. Hal ini berarti ada hubungan yang signifikan antara variabel independen dengan variabel dependen. 
c. Ho diterima dan Ha ditolak jika $\mathrm{t}$ hitung $<\mathrm{t}$ tabel. Hal ini berarti tidak ada hubungan yang signifikan antara variabel independen dengan variabel dependen.

Berikut hasil dari uji t dengan menggunakan SPSS 18.0:

\section{Tabel 1 Hasil Uji t}

\section{Coefficients $^{\text {a }}$}

\begin{tabular}{|c|c|c|c|c|c|c|}
\hline & \multirow{2}{*}{ Model } & \multicolumn{2}{|c|}{$\begin{array}{c}\text { Unstandardized } \\
\text { Coefficients }\end{array}$} & \multirow{2}{*}{$\begin{array}{c}\begin{array}{c}\text { Standardized } \\
\text { Coefficients }\end{array} \\
\text { Beta }\end{array}$} & \multirow{2}{*}{$\mathrm{T}$} & \multirow{2}{*}{ Sig. } \\
\hline & & B & $\begin{array}{l}\text { Std. } \\
\text { Error }\end{array}$ & & & \\
\hline \multirow[t]{4}{*}{1} & (Constant) & 9,998 & 3,462 & & 2,888 & ,005 \\
\hline & Gk.transaksional & ,359 & ,219 & ,203 & 1,642 & , 104 \\
\hline & Gk.transformasional & ,098 &, 157 & ,084 & ,625 &, 533 \\
\hline & Disiplin &, 568 & ,136 & ,451 & 4,193 & ,000 \\
\hline
\end{tabular}

a. Dependent Variable: Kinerja

Sumber: Data Primer Diolah, 2013

Berdasarkan hasil uji t di atas, maka dapat diinterpretasikan sebagai berikut:

1) Variabel Gaya Kepemimpinan Transaksional $\left(X_{1}\right)$



Gambar 3. Kurva Uji t Variabel Gaya Kepemimpinan Transaksional

Dengan nilai $\mathrm{t}$ hitung $=1,642$ maka $(\mathrm{t}$ hitung $<\mathrm{t}$ tabel $)$ dan tingkat signifikan sebesar 0,104 > 0,05 maka $\mathrm{H}_{\mathrm{O}}$ diterima dan Ha ditolak. Jadi dapat disimpulkan variabel gaya kepemimpinan transaksional $\left(\mathrm{X}_{1}\right)$ secara parsial tidak berpengaruh signifikan terhadap kinerja (Y). Hal ini sejalan dengan penelitian yang dilakukan oleh Andira dan Budiarto (2009) mengenai pengaruh gaya kepemimpinan transaksional dan transformasional terhadap kinerja karyawan pada perusahaan jasa.

2) Variabel Gaya Kepemimpinan Transformasional $\left(\mathrm{X}_{2}\right)$

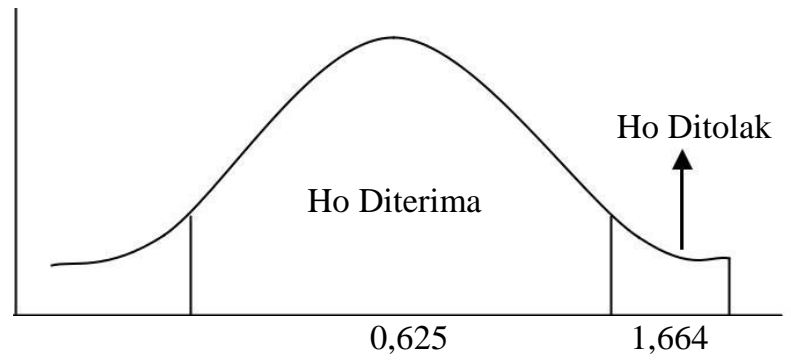

Gambar 4. Kurva Uji t Variabel Gaya Kepemimpinan Transformasional 
Dengan nilai $\mathrm{t}_{\text {hitung }}=0,625$ maka $\left(\mathrm{t}_{\text {hitung }}<\mathrm{t}_{\text {tabel }}\right)$ dan tingkat signifikan sebesar 0,533>0,05 maka $\mathrm{H}_{\mathrm{O}}$ diterima dan Ha ditolak. Jadi dapat disimpulkan

variabel gaya kepemimpinan transformasional $\left(\mathrm{X}_{2}\right)$ secara parsial tidak berpengaruh signifikan terhadap kinerja (Y). Hal ini sejalan dengan penelitian yang dilakukan oleh Andira dan Budiarto (2009) mengenai Pengaruh Gaya Kepemimpinan Transaksional dan Transformasional Terhadap Kinerja Karyawan Pada Perusahaan Jasa. Hasil penelitian menunjukkan bahwa perilaku pada jenis kepemimpinan transformasional mempengaruhi kinerja karyawan secara negatif.

3) Variabel Disiplin $\left(X_{3}\right)$

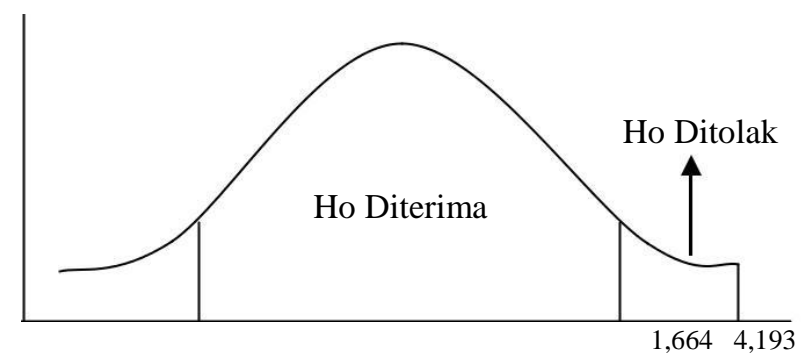

Gambar 5. Kurva Uji t Variabel Gaya Disiplin

Dengan nilai $\mathrm{t}$ hitung $=4,193$ maka $\left(\mathrm{t}_{\text {hitung }}>\mathrm{t}\right.$ tabel $)$ dan tingkat signifikan sebesar 0,00>0,05 maka $\mathrm{H}_{\mathrm{O}}$ ditolak dan Ha diterima. Jadi dapat disimpulkan variabel disiplin $\left(\mathrm{X}_{3}\right)$ secara parsial berpengaruh signifikan terhadap kinerja guru (Y).

\section{Uji F}

Untuk mengetahui pengaruh secara bersama-sama (simultan) antara variabel dependen dengan variabel independen maka digunakan uji $\mathrm{F}$ yang bertujuan untuk mengetahui tingkat pengaruh variabel independen secara bersama-sama terhadap variabel dependen dengan kriteria pengujian sebagai berikut:

1) $\mathrm{H}_{\mathrm{O}} ; \mathrm{b}_{1.2 .3}=0$ artinya, variabel gaya kepemimpinan transaksional $\left(\mathrm{X}_{1}\right)$, gaya kepemimpinan transformasional $\left(\mathrm{X}_{2}\right)$ dan disiplin kerja $\left(\mathrm{X}_{3}\right)$ secara bersama-sama tidak berpengaruh terhadap kinerja guru (Y).

Ha ; $b_{1.2 .3}>0$ artinya, variabel gaya kepemimpinan transaksional $\left(\mathrm{X}_{1}\right)$, gaya kepemimpinan transformasional $\left(\mathrm{X}_{2}\right)$ dan disiplin kerja $\left(\mathrm{X}_{3}\right)$ secara bersama-sama berpengaruh terhadap kinerja guru $(\mathrm{Y})$.

2) $\mathrm{F}_{\text {tabel }}$, df $(\mathrm{n}-\mathrm{k}-1)=90-3-1=$

$86 \mathrm{~F}_{\text {tabel }}(86 ; 3)=2,71$

3) Kriteria pengujian:

- Jika $F$ hitung $\geq F$ tabel, atau signifikan $F \leq 0,05$ maka $\mathrm{H}_{\mathrm{O}}$ ditolak dan Ha diterima.

- Jika $\mathrm{F}$ hitung $\leq \mathrm{F}$ tabel, atau signifikan $\mathrm{F} \geq 0,05$ maka $\mathrm{H}_{\mathrm{O}}$ diterima dan $\mathrm{Ha}$ ditolak.

Berikut hasil uji F : 
Tabel 2. Hasil Uji F

\begin{tabular}{|c|c|c|c|c|c|c|}
\hline \multicolumn{7}{|c|}{ ANOVA $^{b}$} \\
\hline & Model & $\begin{array}{c}\text { Sum of } \\
\text { Squares }\end{array}$ & Df & $\begin{array}{c}\text { Mean } \\
\text { Square }\end{array}$ & $\mathrm{F}$ & Sig. \\
\hline \multirow[t]{3}{*}{1} & Regression & 1505,562 & 3 & \multirow{3}{*}{$\begin{array}{r}501,854 \\
23,592\end{array}$} & \multirow[t]{3}{*}{21,272} & \multirow[t]{3}{*}{, $000^{\mathrm{a}}$} \\
\hline & Residual & 2028,927 & 86 & & & \\
\hline & Total & 3534,489 & 89 & & & \\
\hline
\end{tabular}

a. Predictors: (Constant), Disiplin, Gk.transaksional, Gk.transformasional

b. Dependent Variable: Kinerja

Sumber: Data Primer Diolah, 2013

Berdasarkan hasil pengujian SPSS di atas maka diperoleh nilali $\mathrm{F}$ hitung sebesar 21,272 ( $\mathrm{F}$ hitung $\geq \mathrm{F}$ tabel) dan tingkat signifikan $0,00 \leq 0,05$ maka $\mathrm{H}_{\mathrm{O}}$ ditolak dan Ha diterima yang digambarkan pada kurva di bawah ini:



Gambar 6. Kurva Uji F

Kesimpulannya bahwa variabel gaya kepemimpinan transaksional $\left(\mathrm{X}_{1}\right)$, gaya kepemimpinan transformasional $\left(\mathrm{X}_{2}\right)$ dan disiplin kerja $\left(\mathrm{X}_{3}\right)$ secara bersamasama berpengaruh terhadap kinerja guru(Y).

\section{Analisis Regresi Linier Berganda}

Analisis regresi digunakan untuk mengetahui seberapa besar pengaruh variabel bebas yaitu: gaya kepemimpinan transaksional $\left(\mathrm{X}_{1}\right)$, gaya kepemimpinan transformasional $\left(\mathrm{X}_{2}\right)$ dan disiplin kerja $\left(\mathrm{X}_{3}\right)$ terhadap variabel terikatnya yaitu kinerja guru (Y). Ghozali, 2005 merumuskan regresi berganda sebagai berikut:

$$
\mathrm{Y}=\mathrm{a}+\mathrm{b}_{1} \mathrm{X}_{1}+\mathrm{b}_{2} \mathrm{X}_{2}+\mathrm{b}_{3} \mathrm{X}_{3}+e
$$

Tabel 3 Hasil Analisa Regresi Berganda

\begin{tabular}{|l|l|c|}
\hline \multicolumn{1}{|c|}{ Variabel } & Koeff.regresi & Standart error \\
\hline Gaya kepemimpinan transaksional (X1) & 0,359 & 0,219 \\
\hline Gaya kepemimpinan transformasional (X2) & 0,098 & 0,157 \\
\hline Disiplin kerja (X3) & 0,568 & 0,136 \\
\hline Konstanta & 9,998 & \\
\hline $\mathrm{R}^{2}$ & 0,426 \\
\hline $\mathrm{R}$ & 0,653 & \\
\hline $\mathrm{N}$ & 90 & \\
\hline
\end{tabular}

Sumber: Data Primer Diolah, 2013 
Berdasarkan tabel pengujian di atas maka dapat dirumuskan persamaan sebagai berikut:

$$
\mathrm{Y}=9,998+0,359 \mathrm{X} 1+0,098 \mathrm{X} 2+0,568 \mathrm{X} 3+\mathrm{e}
$$

Dari rumus tersebut dapat diinterpretasikan sebagai berikut:

1) $b_{1}=0,359$, nilai koefisien regresi $\left(X_{1}\right)$ sebesar 0,359 . Jika variabel gaya kepemimpinan transaksional $\left(\mathrm{X}_{1}\right)$ meningkat sebesar 0,359 satu satuan dengan asumsi variabel gaya kepemimpinan transformasional $\left(\mathrm{X}_{2}\right)$ dan disiplin $\left(\mathrm{X}_{3}\right)$ tetap, maka kinerja karyawan $(\mathrm{Y})$ akan meningkat sebesar 0,359 satu satuan.

2) $\mathrm{b}_{2}=0,098$, nilai koefisien regresi $\left(\mathrm{X}_{2}\right)$ sebesar 0,098. Jika variabel gaya kepemimpinan transformasional $\left(\mathrm{X}_{2}\right)$ meningkat 0,098 satu satuan dengan asumsi variabel gaya kepemimpinan transaksional $\left(\mathrm{X}_{1}\right)$ dan disiplin $\left(\mathrm{X}_{3}\right)$ tetap, maka kinerja karyawan $(\mathrm{Y})$ akan meningkat sebesar 0,098 satu satuan.

3) $\mathrm{b}_{3}=0,568$, nilai koefisien regresi $\left(\mathrm{X}_{3}\right)$ sebesar 0,568. Jika variabel disiplin $\left(\mathrm{X}_{3}\right)$ meningkat 0,568 satu satuan dengan asumsi variabel gaya kepemimpinan transaksional $\left(\mathrm{X}_{1}\right)$ dan gaya kepemimpinan transformasional $\left(\mathrm{X}_{2}\right)$ tetap, maka kinerja karyawan (Y) akan meningkat 0,568 satu satuan.

Berdasarkan hasil analisa regresi linier berganda dapat disimpulkan bahwa variabel disiplin $\left(\mathrm{X}_{3}\right)$ mempunyai pengaruh yang lebih besar terhadap kinerja.

\section{J. Analisis Koefisien Korelasi (R)}

Analisa koefisien korelasi (R) digunakan untuk mengetahui hubungan antara variabel independen dengan variabel dependen secara bersama-sama. Berdasarkan hasil uji regresi berganda diperoleh nilai koefisien korelasi (R) sebesar 0,653, hal ini menunjukkan bahwa terdapat hubungan yang kuat dan searah antara variabel gaya kepemimpinan transaksional $\left(\mathrm{X}_{1}\right)$, gaya kepemimpinan transformasional $\left(\mathrm{X}_{2}\right)$ dan disiplin kerja $\left(\mathrm{X}_{3}\right)$ dengan kinerja karyawan (Y).

\section{K. Analisis Koefisien Determinasi (R2)}

Koefisien determinasi $\left(\mathrm{R}^{2}\right)$ digunakan untuk mengetahui tingkat prosentase $(\%)$ pengaruh antara variabel independen dengan variabel dependen. Berdasarkan hasil pengujian regresi linier berganda diperoleh nilai $\mathrm{R}^{2}$ sebesar 0,426 . Hal ini berarti bahwa kinerja karyawan (Y) dipengaruhi variabel gaya kepemimpinan transaksional $\left(\mathrm{X}_{1}\right)$, gaya kepemimpinan transformasional $\left(\mathrm{X}_{2}\right)$ dan disiplin kerja $\left(\mathrm{X}_{3}\right)$ sebesar $42,6 \%$ dan sisanya $57,4 \%$ dipengaruhi oleh faktor lain di luar variabel yang diteliti.

\section{Kesimpulan}

Berdasarkan analisa dan pengujian yang telah dilakukan, maka dapat diperoleh kesimpulan sebagai berikut:

1. Secara parsial disiplin kerja mempunyai konstribusi terhadap kinerja guru dan karyawan. Penerapan disiplin kerja yang baik dapat meningkatkan kinerja karyawan. Dari beberapa variabel bebas yang diteliti variabel disiplin merupakan variabel yang paling dominan mempengaruhi kinerja. 
2. Secara bersama-sama gaya kepemimpinan transaksional, transformasional dan disiplin kerja dapat meningkatkan kinerja guru dan karyawan organisasi sekolah, dikarenakan gaya kepemimpinan transaksional yang lebih menekankan pada pemberian imbalan mendorong guru dan karyawan untuk disiplin terhadap tugas dan tanggung jawabnya untuk mencapai kinerja terbaik. Hal ini tercermin dari kerja guru dan karyawan melaksanakan tugasnya sesuai jam kerja yang ditetapkan, mendorong mereka untuk lebih disiplin dikarenakan tidak adanya kewajiban absen harian di sekolah. Pendekatakan gaya kepemimpian transformasional yang membuat guru dan karyawan diberi kesempatan terlibat dan berpasrtisipasi dalam pengambilan keputusan membuat mereka merasa dihargai dan menjadi bagian dari sekolah untuk mendorong pelaksanaan disiplin dalam melaksanakan tugasnya untuk mewujudkan kinerja yang lebih baik.

\section{J. Saran}

Berdasarkan hasil analisa di yang telah dilakukan, maka saran yang diberikan sebagai berikut:

1. Ruang lingkup studi ini difokuskan pada pengaruh gaya kepemimpinan transaksional, transformasional dan disiplin terhadap kinerja guru dan karyawan sekolah. Keterbatasan ini mengisyaratkan perlunya studi lanjutan dengan variabel lain di perusahaan yang berbeda yang mempunyai hubungan yang signifikan. Sehingga konsep-konsep yang diuji dalam model dapat ditingkatkan validitas eksernalnya.

2. Hasil pengujian yang diperoleh diharapkan dapat digunakan sebagai acuan dalam menerapkan gaya kepemimpinan yang sesuai dengan masing-masing kondisi sekolah sehingga dapat mengoptimalkan kinerja guru dan karayawan

3. Bagi pimpinan sekolah, kepala sekolah diharapkan dapat menerapkan sistem imbalan, promosi jabatan sebagai perwujudan dari gaya kepemimpinan transaksioanl dan melakukan pendekatan interpersonal dengan memberikan motivasi, dan contoh serta melibatkan sguru dan karyawan dalam menyelesaikan permasalahan sekolah sehingga guru dan karyawan merasa sebagai bagian dari sekolah. Hal ini dapat mendorong terwujudnya disiplin yang baik sehingga dapat meningkatkan kinerja guru. 


\section{DAFTAR PUSTAKA}

Andira dan Budiarto. 2009. Pengaruh Perilaku Kepemimpinan Transformasional dan Transaksional Terhadap Kinerja Karyawan Lini Depan Perusahaan Jasa. Jurnal Ekonomi Manajemen.

Cholid dan Achmadi. 2010. Metodologi Peneltian. Jakarta: PT. Bumi Aksara.

Dessler, Gary. 2006. Manajemen Sumber Daya Manusia. Jilid 1. Klaten :PT. Intan Sejati.

Fahmi, Irham. 2012. Manajemen Kepemimpinan Teori dan Aplikasi. Bandung: CV Alfabeta.

Imam, Ghozali. 2006. Statistik Non Parametik. Semarang: Badan Penerbit UNDIP.

Kaswan. 2012. Manajemen Sumber Daya Manusia Untuk Keunggulan Bersaing Organisasi. Yogyakarta: Graha Ilmu.

Munawaroh. 2011. Pengaruh Gaya Kepemimpinan Transformasional dan Transaksional terhadap Kinerja Guru SMP katolik Wijana Jombang. Jurnal Ekonomi Bisnis.

Nazir, Moh.1999. Metode Penelitian. Jakarta: Ghalia Indonesia

Rangkuti. 2002. Aplikasi Statistik. Jakarta: PT. Gramedia Pustaka.

Robbins dan Coulter. 2005. Manajemen. Jilid II. Jakarta: PT. Indeks Kelompok Gramedia.

Sekaran, Uma. 2010. Research Methode For Business. John Wiley \& Sons, Inc.

Stoner, Freeman dan Gilbert. 2001. Manajemen. Jilid I. Jakarta: PT. Indeks Gramedia Grup.

Stoner, Freeman dan Gilbert. 2003. Manajemen. Jilid II. Jakarta: PT. Indeks Gramedia Grup.

Suharsimi, Arikunto. 2006. Prosedur Penelitian Suatu Pendekatan Praktek. Jakarta:Rineka Cipta.

Usnul Khotimah. 2013. Pengaruh Gaya Kepemimpinan Transformasional dan Disiplin Terhadap Kinerja Karyawan Tetap Pada PT. Sari Lembah Subur Pelalawan. Riau.

Veithzal Rivai dan Ahmad Fawzi Mohd Basri. 2005. Performance Appraisal Sistem Yang Tepat Untuk Menilai Kinerja Karyawan dan Meningkatkan Daya Saing Perusahaan. Jakarta: PT. Raja Grafindo Persada.

Veithzal Rivai dan Jauvani Sagala. 2009. Manajemen Sumber Daya Manusia untuk Perusahaan. Jakarta: PT. Raja Grafindo Persada. 